\title{
COVID-19 Barometer: Social Opinion - What Do the Portuguese Think in This Time of COVID-19?
}

\author{
Ana Rita Pedro ${ }^{a, b}$ Ana Gama ${ }^{a, b}$ Patrícia Soares ${ }^{a, b}$ Marta Moniz ${ }^{a, b}$ \\ Pedro A. Laires ${ }^{a}$ b Sónia Dias ${ }^{a, b}$ \\ aNOVA National School of Public Health, Public Health Research Centre, Universidade NOVA de Lisboa, \\ Lisbon, Portugal; ${ }^{b}$ Comprehensive Health Research Center (CHRC), Lisbon, Portugal
}

\section{Keywords}

COVID-19· Social opinion · Quantitative methods · Social perception · Community-based survey

\begin{abstract}
The COVID-19 pandemic brought new challenges to the global community, reinforcing the role of public health in society. The main measures to combat it had (and still have) a huge impact on the daily lives of citizens. This investigation aimed to identify and monitor the population's perceptions about how it faced this period and the impact on health, well-being, and daily life. In this study, we describe the main trends observed throughout the COVID-19 pandemic in terms of mental health status, confidence in the capacity of the health services to respond to the pandemic, and the use of health services by participants. The online survey collected responses from 171,947 individuals $\geq 16$ years of age in Portugal, over a period of 15 weeks that started on 21 March 2020. Participants could fill the questionnaire once or weekly, which enabled us to analyse trends and variations in responses. Overall, $81 \%$ of the respondents reported having felt agitated, anxious, or sad during the COVID-19 pandemic; $19 \%$ did not experience these feelings. During the confine-
\end{abstract}

ment period, the proportion of participants feeling agitated, anxious, or sad every day/almost every day ranged between 20 and $30 \%$, but since the deconfinement this proportion decreased. Around $30 \%$ reported having more difficulty getting to sleep or to sleep all night; $28.4 \%$ felt more agitated; $25.5 \%$ felt sadder, discouraged, or cried more easily; and $24.7 \%$ felt unable to do everything they had to do, women more frequently than men. Overall, $65.8 \%$ of the participants reported feeling confident or very confident in the health services' capacity to respond to the challenges associated with the pandemic, and this confidence increased over time. Concerning the people who needed a consultation, 35.6\% had one in person and $20.8 \%$ had one remotely, but almost $44 \%$ did not have one due to cancellation by the service (27.2\%) or their own decision not to go (16.3\%). At this unusual time in which we find ourselves and based on our findings, it is essential to continue monitoring how the population is facing the different phases of the pandemic until it officially ends. Analysing the effects of the pandemic from the point of view of citizens allows for anticipating critical trends and can contribute to preventative action.

(c) 2021 The Author(s). Published by S. Karger AG, Base on behalf of NOVA National School of Public Health karger@karger.com www.karger.com/pjp

Karger $\stackrel{\text { ' }}{5}$

BOPEN ACCESS (c) 2021 The Author(s). Published by S. Karger AG, Basel on behalf of NOVA National School of Public Health

This article is licensed under the Creative Commons AttributionNonCommercial-NoDerivatives 4.0 International License (CC BYNC-ND) (http://www.karger.com/Services/OpenAccessLicense) Usage and distribution for commercial purposes as well as any distribution of modified material requires written permission.
Ana Rita Pedro

NOVA National School of Public Health, Universidade NOVA de Lisboa Avenida Padre Cruz

PT-1600-560 Lisbon (Portugal)

rita.pedro@ensp.unl.pt 
Barómetro COVID-19: Opinião Social - o que pensam os portugueses em tempos de COVID-19?

\section{Palavras Chave}

COVID-19 · Opinião social · Métodos quantitativos .

Perceção social · Estudo baseado na comunidade

\section{Resumo}

A COVID-19 trouxe novos desafios à comunidade global, reforçando o papel da Saúde Pública na sociedade. As principais medidas para a combater tiveram (e ainda têm) um enorme impacto no quotidiano dos cidadãos. O "Barómetro COVID-19: Opinião Social - o que pensam os portugueses no tempo da COVID-19?," teve como objetivo identificar e acompanhar as percepções da população sobre como enfrentaram este período e o seu impacto na sua saúde, bem-estar e vida diária. Neste estudo descrevemos as principais tendências observadas durante a pandemia em termos de saúde mental, confiança na capacidade de resposta dos serviços de saúde e utilização dos serviços de saúde. $O$ inquérito online recolheu respostas de 171 '947 indivíduos com $\geq 16$ anos em Portugal, durante 15 semanas consecutivas, iniciado a 21 de março de 2020. Os participantes puderam preencher o questionário uma vez ou semanalmente, o que permitiu analisar tendências e variações nas respostas. No geral, $81 \%$ dos entrevistados relataram ter-se sentido agitado, ansioso ou triste durante a pandemia de Covid-19; 19\% nunca experienciaram estes sentimentos. Durante o confinamento, a proporção de participantes que relatou estes sentimentos de agitação, ansiedade ou tristeza todos os dias / quase todos os dias variou entre $20-30 \%$, mas desde o desconfinamento esta proporção diminuiu. Quanto a outros efeitos, $29,8 \%$ relataram ter mais dificuldade para dormir ou dormir a noite toda, $28,4 \%$ se sentiram mais irritantes, $25,5 \%$ se sentiram mais tristes, desanimados ou choraram com mais facilidade e $24,7 \%$ se sentiram incapazes de fazer tudo o que tinha que fazer, com maior frequência mulheres homens. Globalmente, no que se refere à confiança na capacidade de resposta dos serviços de saúde à COVID-19, 65,8\% dos participantes relataram estar confiantes ou muito confiantes, e em termos de tendências a confiança aumentou ao longo do tempo. Em relação às pessoas que necessitaram de consulta, 35,6\% realizaram-na presencialmente e $20,8 \%$ remotamente, mas quase $44 \%$ não a realizaram porque o seviço cancelou $(27,2 \%)$ ou por decisão própria de não comparecer (16,3\%). Num período atípico como o que vivemos, e com

COVID-19 Barometer: Social Opinion base em nossos resultados, é fundamental continuar a monitorizar como a população está a enfrentar as diferentes fases da pandemia, até que seja declarado o seu fim. Além da análise dos efeitos da pandemia, sob o ponto de vista dos cidadãos, também podemos antecipar tendências críticas e agir preventivamente.

๑ 2021 The Author(s). Published by S. Karger AG, Basel on behalf of NOVA National School of Public Health

\section{Introduction}

The emergence of SARS-CoV-2 and consequently coronavirus disease 2019 (COVID-19) pandemic [1], which currently account for $>34$ million individuals being infected and $>1$ million deaths worldwide [2], was an unparalleled and unpredictable phenomenon in contemporary society, for which no country was prepared. Unquestionably, this pandemic has brought new challenges to the global community, reinforcing the role of public health in society [3]. Governments all over the world have been forced to make unprecedented strategic and political decisions. The COVID-19 crisis has affected all sectors of society. The main measures to combat the pandemic, i.e., protective equipment, physical distancing, confinement, quarantine, and isolation, have had a huge impact on the daily lives of citizens, who have had to adapt to a new way of living in society. One of the great challenges is that this pandemic affects all populations and groups, although in different ways [4-6], further accentuating already existing social and health inequalities [7].

This fast-spreading infectious disease has led to universal awareness, anxiety, and distress, natural psychological responses to an unexpected changing condition [8-10]. Therefore, it is important to analyse how COVID-19 is impacting the population's mental health [1113].

The first case of COVID-19 in Portugal was reported on 2 March 2020 [14]. Similar to other European countries, after a first phase of a "track-and-trace" response and quarantining at-risk individuals to contain the spread of infection, the second phase of "Confinement" (state of emergency measures and a partial lockdown) was initiated on 18 March 2020. This response aimed to reduce the rate of transmission by implementing social distancing and increase the capacity of the National Health Service (NHS) by increasing hospitals' response, human resources, and beds with ventilators. As a social distancing measure, the population was restricted to staying at home from March to May [15]. 
Table 1. Sociodemographic characteristics of the participants

\begin{tabular}{|c|c|c|c|}
\hline & Total, $n(\%)$ & Females, $n(\%)$ & Males, $n(\%)$ \\
\hline \multicolumn{4}{|l|}{ Age group $(n=171,756)$} \\
\hline $16-25$ years & $17,939(10.4)$ & $13,172(11.9)$ & $4,767(7.8)$ \\
\hline $26-45$ years & $82,494(48.0)$ & $55,118(49.8)$ & $27,376(44.9)$ \\
\hline $46-65$ years & $61,446(35.8)$ & $37,833(34.2)$ & $23,613(38.7)$ \\
\hline$>65$ years & $9,877(5.8)$ & $4,595(4.2)$ & $5,282(8.7)$ \\
\hline \multicolumn{4}{|l|}{ Level of education $(n=170,927)$} \\
\hline Basic & $10,584(6.2)$ & $5,534(5.0)$ & $5,050(8.3)$ \\
\hline Secondary & $46,896(27.4)$ & $27,925(25.3)$ & $18,971(31.2)$ \\
\hline Higher & $113,447(66.4)$ & $76,741(69.6)$ & $36,706(60.4)$ \\
\hline \multicolumn{4}{|l|}{ Residence area $(n=171,563)$} \\
\hline Lisboa e Vale do Tejo & $77,618(45.2)$ & $50,214(45.4)$ & $27,404(45.0)$ \\
\hline Norte & $44,916(26.2)$ & $28,713(26.0)$ & $16,203(26.6)$ \\
\hline Centro & $25,525(14.9)$ & $16,514(14.9)$ & $9,011(14.8)$ \\
\hline Alentejo & $6,635(3.9)$ & $4,349(3.9)$ & $2,286(3.7)$ \\
\hline Algarve & $6,354(3.7)$ & $4,172(3.8)$ & $2,182(3.6)$ \\
\hline Região Autónoma dos Açores & $5,340(3.1)$ & $3,431(3.1)$ & $1,909(3.1)$ \\
\hline Região Autónoma da Madeira & $3,696(2.2)$ & $2,380(2.2)$ & $1,316(2.2)$ \\
\hline Outside Portugal & $1,479(0.9)$ & $828(0.7)$ & $651(1.1)$ \\
\hline \multicolumn{4}{|c|}{ Monthly household income $(n=150,885)$} \\
\hline$<650$ EUR & $10,734(7.1)$ & $7,837(8.1)$ & $2,897(5.4)$ \\
\hline 651-1,000 EUR & $25,888(17.2)$ & $18,147(18.7)$ & $7,741(14.4)$ \\
\hline 1,001-1,500 EUR & $34,460(22.8)$ & $23,659(24.4)$ & $10,801(20.0)$ \\
\hline $1,501-2,000$ EUR & $28,422(18.8)$ & $18,499(19.1)$ & $9,923(18.4)$ \\
\hline 2,001-2,500 EUR & $21,319(14.1)$ & $13,044(13.5)$ & $8,275(15.3)$ \\
\hline$>2,501$ EUR & $30,062(19.9)$ & $15,759(16.3)$ & $14,303(26.5$ \\
\hline \multicolumn{4}{|l|}{ Occupation $(n=171,756)$} \\
\hline Student & $11,392(6.6)$ & $8,304(7.5)$ & $3,088(5.1)$ \\
\hline Employee & $104,201(60.7)$ & $68,519(61.9)$ & $35,682(58.5)$ \\
\hline Self-employed & $25,396(14.8)$ & $14,643(13.2)$ & $10,753(17.6)$ \\
\hline Domestic & $2,006(1.2)$ & $1,927(1.7)$ & $79(0.1)$ \\
\hline Retired & $11,841(6.9)$ & $5,867(5.3)$ & $5,974(9.8)$ \\
\hline Unemployed & $7,720(4.5)$ & $5,448(4.9)$ & $2,272(3.7)$ \\
\hline Other & $9,200(5.4)$ & $6,010(5.4)$ & $3,190(5.2)$ \\
\hline \multicolumn{4}{|c|}{ Living alone or not alone $(n=171,190)$} \\
\hline Alone & $20,488(12.0)$ & $13,234(12.0)$ & $7,254(11.9)$ \\
\hline Not alone & $150,702(88.0)$ & $97,047(88.0)$ & $53,655(88.1)$ \\
\hline
\end{tabular}

The National School of Public Health at the NOVA University of Lisbon (ENSP/NOVA) launched the research project "COVID-19 Barometer: Social Opinion: What Do the Portuguese Think in This Time of COVID-19?" to identify and monitor the population's perceptions about how they faced this period and its impact on their health, well-being, and daily life.

In this study, we describe the main trends observed throughout the COVID-19 pandemic in terms of mental health status, confidence in the health services' responsiveness, and the use of the health services by the participants from 21 March to 27 June 2020. This kind of information is very important to identify the effects of the pan- demic, anticipate critical trends, and act preventatively as well as identify relevant information to inform and educate the general public.

\section{Materials and Methods}

The community-based survey "COVID-19 Barometer: Social Opinion" obtained responses from 171,947 individuals $\geq 16$ years of age in Portugal over a period of 15 weeks. Participants could fill the online questionnaire once or weekly, which enabled us to analyse trends and variations in responses. Potential participants were invited to participate by means of (i) existing contact networks and mailing lists, (ii) digital social networks, (iii) social media promo- 
Table 2. Frequency of feeling agitated, anxious, or sad during the COVID-19 pandemic according to sex, age, educational level, and monthly income

\begin{tabular}{|c|c|c|c|c|c|}
\hline & $\begin{array}{l}\text { Every day, } \\
n(\%)\end{array}$ & $\begin{array}{l}\text { Almost every day, } \\
n(\%)\end{array}$ & $\begin{array}{l}\text { Some days, } \\
n(\%)\end{array}$ & $\begin{array}{l}\text { Never, } \\
n(\%)\end{array}$ & $p$ value \\
\hline Total & $14,959(9.6)$ & $26,108(16.7)$ & $85,621(54.8)$ & $29,468(18.9)$ & \\
\hline Sex & & & & & $<0.001$ \\
\hline Female & $12,034(10.9)$ & $19,758(17.9)$ & $62,142(56.4)$ & $16,261(14.8)$ & \\
\hline Male & $4,283(7.1)$ & $8,685(14.3)$ & $31,524(52.0)$ & $16,111(26.6)$ & \\
\hline Age group, years & & & & & $<0.001$ \\
\hline $16-25$ & $2,304(12.9)$ & $4,112(23.1)$ & $9,282(52.1)$ & $2,116(11.9)$ & \\
\hline $26-45$ & $8,554(10.4)$ & $14,535(17.7)$ & $46,037(56.0)$ & $13,047(15.9)$ & \\
\hline $46-65$ & $4,927(8.1)$ & $8,668(14.2)$ & $33,195(54.3)$ & $14,355(23.5)$ & \\
\hline$>65$ & $555(5.6)$ & $1,160(11.8)$ & $5,234(53.2)$ & $2,885(29.3)$ & \\
\hline Educational level & & & & & $<0.001$ \\
\hline Basic & $1,442(13.8)$ & $2,046(19.6)$ & $5,202(49.8)$ & $1,756(16.8)$ & \\
\hline Secondary & $5,088(10.9)$ & $8,521(18.3)$ & $24,884(53.4)$ & $8,126(17.4)$ & \\
\hline Higher & $9,718(8.6)$ & $17,746(15.7)$ & $63,262(55.9)$ & $22,378(19.8)$ & \\
\hline Monthly household income & & & & & $<0.001$ \\
\hline$<650$ EUR & $1,547(14.5)$ & $2,160(20.3)$ & $5,443(51.1)$ & $1,495(14.0)$ & \\
\hline 651-1,000 EUR & 3,009 (11.7) & $4,944(19.2)$ & $13,891(53.9)$ & $3,906(15.2)$ & \\
\hline 1,001-1,500 EUR & $3,495(10.2)$ & $5,855(17.0)$ & $19,050(55.5)$ & $5,944(17.3)$ & \\
\hline 1,501-2,000 EUR & $2,515(8.9)$ & $4,541(16.0)$ & $16,035(56.6)$ & $5,241(18.5)$ & \\
\hline $2,001-2,500$ EUR & $1,687(7.9)$ & $3,296(15.5)$ & $11,886(55.9)$ & $4,399(20.7)$ & \\
\hline$>2,500$ EUR & $1,977(6.6)$ & $4,079(13.6)$ & $16,313(54.3)$ & $7,652(25.5)$ & \\
\hline
\end{tabular}

tion, and (iv) partnerships with third-sector organisations including patient associations, municipalities, and groups of health-care professionals.

Data was collected using a structured, closed-ended questionnaire administered online via the Microsoft Forms software program. The questionnaire was developed based on the National Health Survey regarding the sociodemographic characteristics of respondents, health status, and health care utilisation indicators [16]. Specific questions about COVID-19 were created by the authors and based on the COVID-19 Rapid Quantitative Assessment Tool of the WHO whenever possible [17]. The questionnaire was pretested to verify response times, ensure comprehensibility, and solve operational errors.

Sociodemographic characteristics included sex, age, education level, monthly household income, residence area, how professional activity was carried out, and loss of income. Participants were asked about how frequently they felt agitated, anxious, or sad, how they felt most of the time, and what they did day-to-day to deal with the current situation. Participants were also asked about their level of confidence in the capacity of the health services to respond to the pandemic and whether they had need of a consultation during the COVID-19 pandemic.

\section{Data Analysis}

Sociodemographic variables were summarised as absolute and relative frequencies. The characterisation of the participants and analyses were stratified by sex. The $\chi^{2}$ test was used to assess independence between some core sociodemographic variables and mental health status, daily behaviours, and need of consultation. The trends were analysed regarding mental health status, level of confidence in the health services' capacity, and the need for consultation, based on the weekly responses of participants. All analyses were conducted with IBM SPSS Statistics v26.

\section{Results}

Throughout the 15 weeks, 171,947 people participated in this study, $65 \%$ of whom were women and $35 \%$ men; $10.4 \%$ were $\geq 25$ years of age, $48 \%$ were $26-45$ years of age, and $35.8 \%$ were $46-65$ years of age. Table 1 shows the sociodemographic characteristics of the participants.

Overall, $81 \%$ reported feeling agitated, anxious, or sad during the COVID-19 pandemic ( $54.8 \%$ some days, $16.6 \%$ almost every day, and 9.6\% every day); 19\% did not experience these feelings. Feeling frequently agitated, anxious, or sad was more often reported by women, younger participants (aged 16-25 years), those with a basic educational level, and those with a low income (<650 EUR; Table 2). During the confinement, the proportion of participants that reported feeling agitated, anxious, or sad every day/ almost every day ranged between 20 and 30\%, but this proportion decreased since deconfinement (Fig. 1). No relationship was found between feeling agitated, anxious, or sad and whether the participant lived alone or not. 


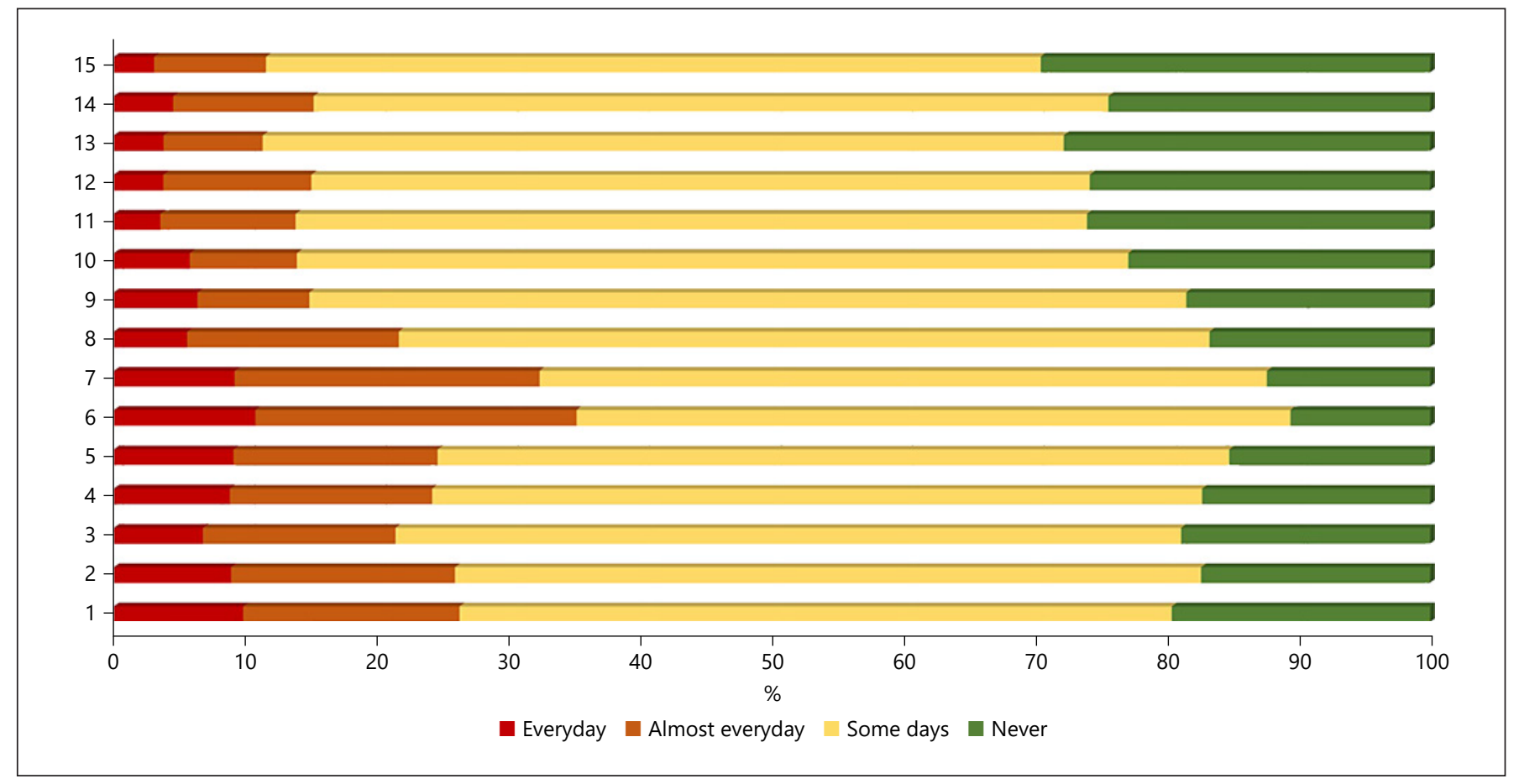

Fig. 1. Weekly trends of feeling agitated, anxious, or sad during the COVID-19 pandemic.

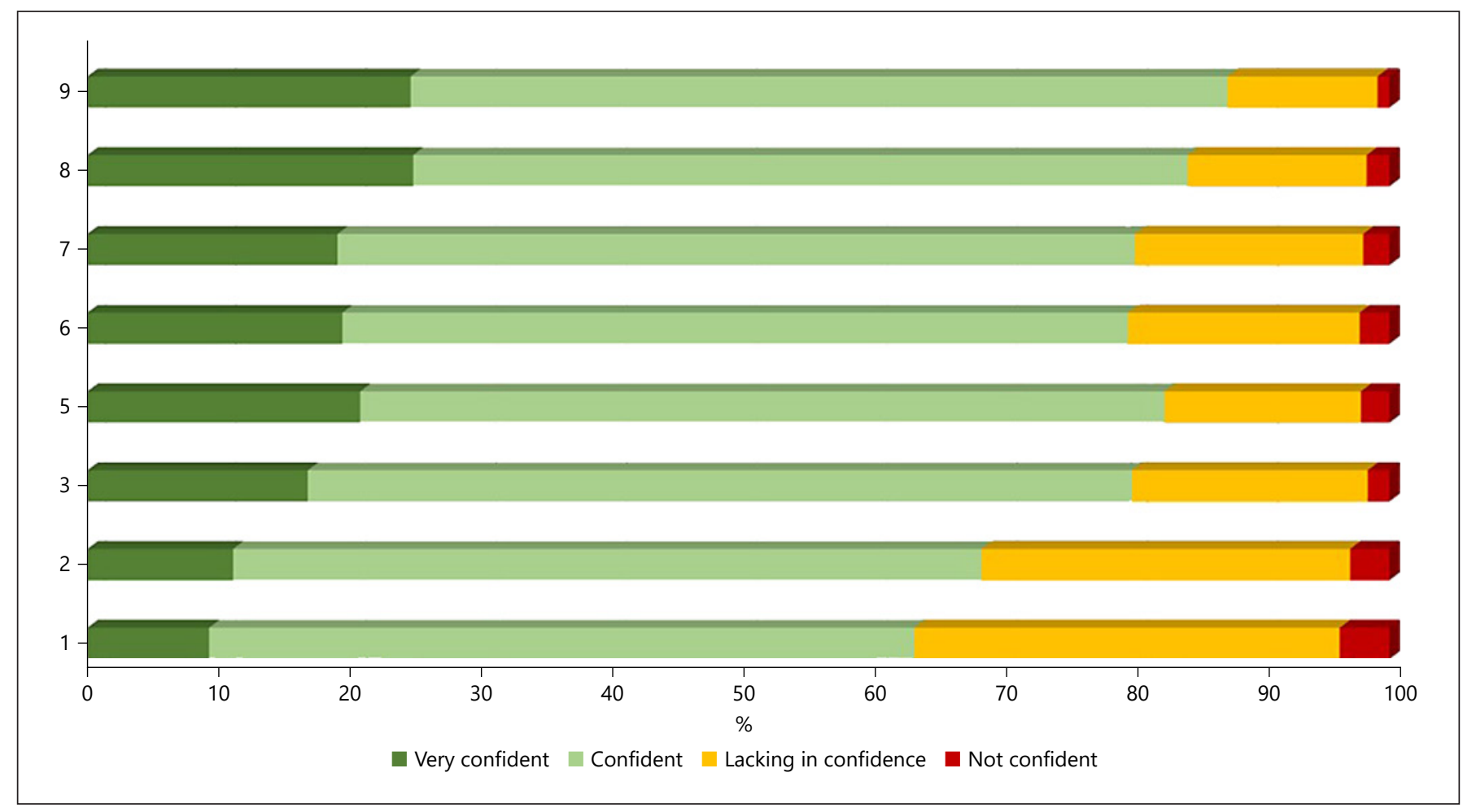

Fig. 2. Weekly trends of the level of confidence in the health services' capacity to respond to the pandemic. 
Table 3. Medical consultation/appointments during the COVID-19 period, by sex, age, educational level, and income

\begin{tabular}{|c|c|c|c|c|c|}
\hline Total & $718(35.6)$ & $420(20.8)$ & $328(16.3)$ & $549(27.2)$ & \\
\hline Sex & & & & & 0.167 \\
\hline Female & $563(36.3)$ & $331(21.3)$ & $250(16.1)$ & $407(26.2)$ & \\
\hline Male & $204(33.2)$ & $118(19.2)$ & $109(17.7)$ & $184(29.9)$ & \\
\hline $26-45$ years & $334(38.1)$ & $161(18.4)$ & $145(16.5)$ & $237(27.0)$ & \\
\hline $46-65$ years & $271(33.7)$ & $189(23.5)$ & $116(14.4)$ & $227(28.3)$ & \\
\hline$>65$ years & $66(30.8)$ & $53(24.8)$ & $29(13.6)$ & $66(30.8)$ & \\
\hline Educational level & & & & & $<0.001$ \\
\hline Basic & $43(26.2)$ & $38(23.2)$ & $26(15.9)$ & $57(34.8)$ & \\
\hline Secondary & $152(29.5)$ & $113(21.9)$ & $99(19.2)$ & $151(29.3)$ & \\
\hline $1,001-1,500$ EUR & $122(32.9)$ & $89(24.0)$ & $53(14.3)$ & $107(28.8)$ & \\
\hline $1,501-2,000$ EUR & $116(35.2)$ & $65(19.7)$ & $62(18.8)$ & $87(26.4)$ & \\
\hline 2,001-2,500 EUR & $93(35.4)$ & $71(27.0)$ & $36(13.7)$ & $63(24.0)$ & \\
\hline$>2,500$ EUR & $230(45.4)$ & $85(16.8)$ & $65(12.8)$ & $127(25.0)$ & \\
\hline
\end{tabular}

Around 30\% reported having more difficulty getting to sleep or sleeping all night; $28.4 \%$ felt more agitated; $25.5 \%$ felt sadder, discouraged, or cried more easily; and $24.7 \%$ felt unable to do everything they had to do, more frequently women than men. When asked about the coping mechanisms to deal with the lockdown, women reported more frequently than men to have maintained their contact with family and friends even at a distance, tried to establish daily routines, limited the information they watched about COVID-19, and practised physical exercise, but also to have eaten more sweets, fats, and caloric food. Men reported more frequently than women to have taken the time at home to do things they liked but also to have smoked more or drunk more alcohol. Those who adopted unhealthy behaviours reported more frequently feeling anxious. On the other hand, people who practised physical activity and who took time to do activities that give them pleasure who reported feeling anxious less frequently.

Overall, $65.8 \%$ of the participants reported feeling confident or very confident in the health services capacity to respond to the pandemic, but over one-third reported being unsure or not confident at all. The participants who reported they were less confident were 26-45 years of age (33.7\% unsure and $4 \%$ not confident at all), versus $46-65$ years $(28.4 \%$ unsure and $3.3 \%$ not confident at all), $>65$ years ( $21 \%$ unsure and $1.9 \%$ not confident at all) $(p<0.01)$ and had a higher education $(32.3 \%$ unsure and $3.7 \%$ not confident), versus those with a secondary education only (28.5\% unsure and $3.3 \%$ not confident), or a basic education (25.2\% unsure and 3.4\% not confident). As shown in Figure 2, the participants' confidence in the health services capacity to respond to the pandemic increased over time.

Overall, $67.0 \%(n=4,542)$ of the participants reported having not needed a medical consultation during the COVID-19 period. The remaining 2,241 people needed a consultation; $35.6 \%$ had one in person and $20.8 \%$ had one remotely, but almost $43.5 \%$ did not have one due to cancellation by the service $(27.2 \%)$ or their own decision to not attend (16.3\%). Respondents with a lower income reported more frequently not having had the consultation they needed. The participants who did not have the consultation due to it being cancelled by the service were significantly older and had basic education. Participants who decided themselves to not have the consultation they needed were significantly younger and had a secondary education (Table 3). While in the first weeks of confinement most participants who needed a medical consultation did not have one, this proportion progressively decreased throughout the deconfinement period (Fig. 3). It is noteworthy that the proportion of participants having 


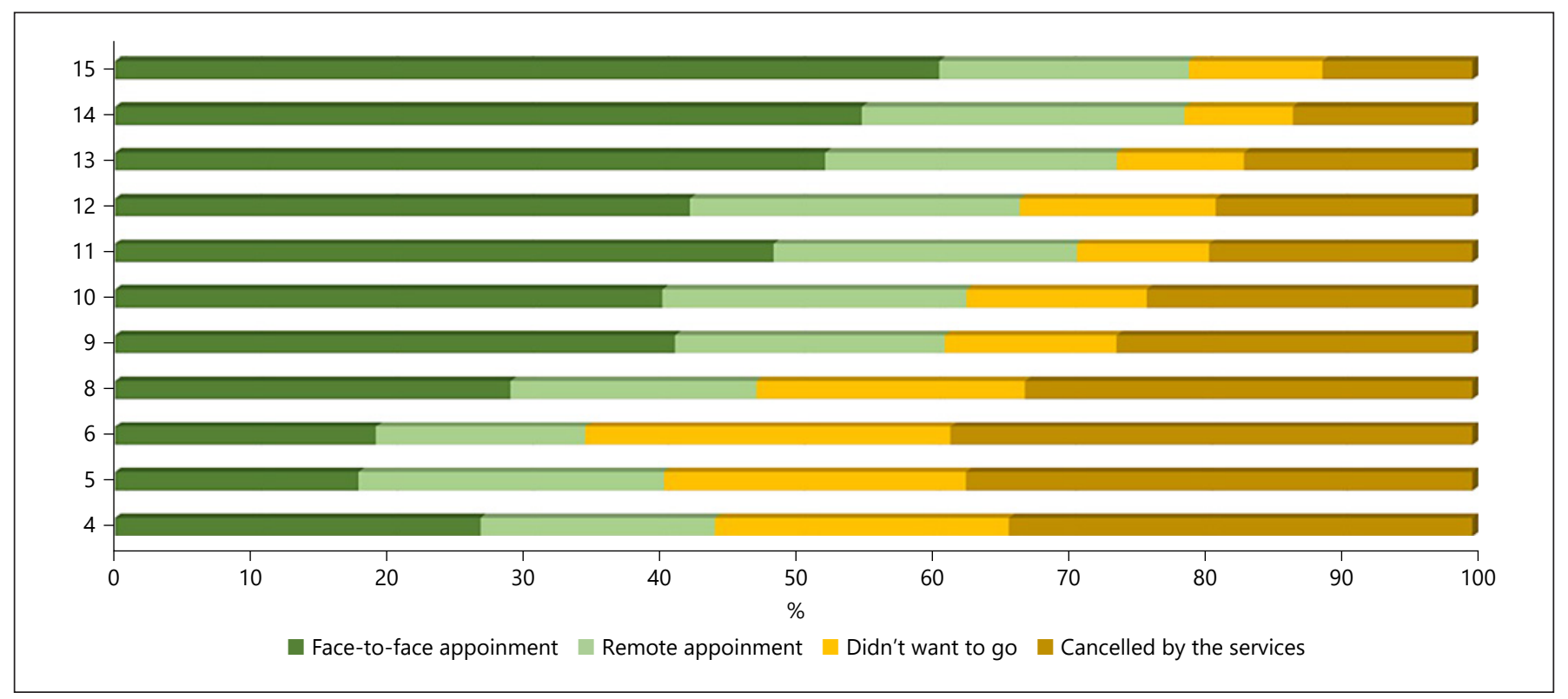

Fig. 3. Weekly trends of medical consultations taking place during the COVID-19 pandemic.

remote consultations remained relatively stable after the confinement period $(>20 \%)$, even with the increased number of consultations in person.

\section{Discussion}

Our results confirm that the lockdown between March and May had an impact on mental health and anxiety, especially among women and the working-age population. These findings are in line with other recently published studies conducted in China [18-21], India [22], Denmark [23], and Spain [24]. A recent review reported that confinement is associated with increased psychological distress, diagnostic symptoms of post-traumatic stress disorder (PTSD), depression, and greater levels of stress [25]. A systematic review and meta-analysis of the impact of the pandemic on an individual's mental health indicate that anxiety and depression are often $>20 \%$ prevalent, with differences according to gender and occupation [26]. Our findings also reveal that individuals adopted several strategies to cope with the lockdown experience. Many of these strategies have a potentially positive impact on mental health, e.g., practising physical activity and spending time doing pleasurable/leisure activities, but some others are risk behaviors (e.g., increased smoking and alcohol consumption). The prolonged stay at home, with changes in routines and a substantial reduc- tion in physical activity/an increase in sedentary habits can have an impact on health. It is thus crucial that strategies for adopting healthy behaviours that assist individuals in coping with the pandemic situation are developed and widely disseminated, namely in the areas of healthy eating and promoting physical activity.

As part of the response measures to increase the NHS inpatient capacity, NHS hospitals in Portugal, like others worldwide, suspended all non-urgent elective surgery to increase bed capacity and free up theatre ventilators to be used for COVID-19 patients. As a result, a significant number of the people who needed consultations did not have them due to cancellation by the services. Nevertheless, it is noteworthy that people revealed that they trusted in the capacity of the health services to respond to the demands of COVID-19, and this confidence has increased with the evolution of the pandemic.

Our findings also show that the pandemic is affecting populations asymmetrically and having a greater impact on the most vulnerable, including more disadvantaged groups, and potentially accentuating health inequalities. In fact, feelings of agitation, anxiety, or sadness were more frequently reported by participants with a basic level of education and lower incomes, besides women, and younger participants. Also, those who reported not having had a consultation (either because the service cancelled it or by participant's own decision) reported more frequently having a lower income. It is therefore impor- 
tant to develop strategies that prevent health and social inequalities from growing further.

Some limitations must be acknowledged. The sample is not representative. The fact that the survey was conducted online meant that only people with e-mail and/or a presence in social networks were able to participate. The variability of the number of respondents across different weeks, with the vast majority having participated in the first 4 weeks of the study (during the confinement period) must also be taken into account when interpreting the results. The survey may have been subject to volunteer bias (e.g., more engaged and informed citizens tend to adhere to measures) and social desirability bias. Nevertheless, the anonymous online nature of this survey may have served to minimise these impacts. The study was based on the analysis of self-reported data, which might be subject to recall bias.

This study has several strengths too. This communitybased survey reached $>170,000$ people, which, to our knowledge, makes it one of the largest community-based surveys performed on COVID-19 so far to collect data on individuals' perceptions and behaviours when faced with the present situation, and it allowed us to analyse trends during the weeks of confinement and the first weeks of deconfinement in a dynamic way.

In this unusual time we are living in, and based on our findings, it is essential to continue monitoring how the population is facing the different phases of the pandemic until its end is declared. The "COVID-19 Barometer: Social Opinion" is a powerful data collection tool for this purpose. In addition to analyses of the pandemic effects from the point of view of citizens, we can also use it to anticipate critical trends and act preventatively.

\section{Statement of Ethics}

The study was approved by the Ethics Commission of the NOVA National School of Public Health (ref. CE/ENSP/ CREE/2/2020). The research conformed with the guidelines for human studies and was conducted ethically in accordance with the World Medical Association Declaration of Helsinki. Anonymity of participants and confidentiality of data were guaranteed. Informed consent was obtained from all participants.

\section{Conflict of Interest Statement}

The authors have no conflicts of interest to declare.

\section{Funding Sources}

This study was co-financed by the Foundation for Science and Technology, under the financing program "Research 4 Covid-19".

\section{Author Contributions}

A.R.P., A.G., and S.D.: concept and design; A.R.P., A.G., P.L., and S.D.: acquisition, analysis, and interpretation of data; A.R.P. and A.G.: drafting of the manuscript; P.S. and M.M.: statistical analysis; S.D. and A.R.P.: supervision. All authors critically revised the manuscript for important intellectual content.

\section{References}

1 WHO. WHO Director-General's opening remarks at the media briefing on COVID-19: 11 March 2020. Published March 11, 2020. Geneva: WHO; 2020. [cited October 3, 2020]. Available from: https://www.who.int/dg/ speeches/detail/who-director-general-sopening-remarks-at-the-media-briefing-oncovid-19--11-march-2020.

2 Johns Hopkins University. CSSE. Coronavirus COVID-19 global cases by the Center for Systems Science and Engineering (CSSE) at Johns Hopkins University: updated October 3, 2020. Baltimore, MA: CSSE; 2020. [cited October 3, 2020]. Available from: https:// gisanddata.maps.arcgis.com/apps/opsdashboard/index.html\#/bda $7594740 \mathrm{fd}$ 40299423467b48e9ecf6.

3 Pan A, Liu L, Wang C, Guo H, Hao X, Wang $\mathrm{Q}$, et al. Association of public health interventions with the epidemiology of the COVID-19 outbreak in Wuhan, China. JAMA. 2020 May; 323(19):1915-23.
4 Tsai J, Wilson M. COVID-19: a potential public health problem for homeless populations. Lancet Public Health. 2020 Apr;5(4):e186-7.

5 Grasselli G, Zangrillo A, Zanella A, Antonelli M, Cabrini L, Castelli A, et al.; COVID-19 Lombardy ICU Network. Baseline characteristics and outcomes of 1591 patients infected with SARSCoV-2 admitted to ICUs of the Lombardy region, Italy. JAMA. 2020 Apr;323(16):1574-81.

6 Yancy CW. COVID-19 and African Americans. JAMA. 2020 May;323(19):1891-2.

7 Ahmed F, Ahmed N, Pissarides C, Stiglitz J. Why inequality could spread COVID-19. Lancet Public Health. 2020 May;5(5):e240.

8 Kluge HN. Statement: physical and mental health key to resilience during COVID-19 pandemic. Geneva: WHO; 2020. [cited October 27, 2020], Available from http://www. euro.who.int/en/health-topics/health-emergencies/coronavirus-covid-19/statements/ statement-physical-and-mental-health-keyto-resilience-during-covid-19-pandemic.
$9 \operatorname{Sim~K,~Chua~HC.~The~psychological~impact~of~}$ SARS: a matter of heart and mind. CMAJ. 2004 Mar; 170(5):811-2.

10 Wu P, Fang Y, Guan Z, Fan B, Kong J, Yao Z, et al. The psychological impact of the SARS epidemic on hospital employees in China: exposure, risk perception, and altruistic acceptance of risk. Can J Psychiatry. 2009 May; 54(5):302-11.

11 Shigemura J, Ursano RJ, Morganstein JC, Kurosawa $M$, Benedek DM. Public responses to the novel 2019 coronavirus (2019-nCoV) in Japan: mental health consequences and target populations. Psychiatry Clin Neurosci. 2020 Apr;74(4):281-2.

12 Lima CK, Carvalho PM, Lima IA, Nunes JV, Saraiva JS, de Souza RI, et al. The emotional impact of Coronavirus 2019-nCoV (new Coronavirus disease). Psychiatry Res. 2020 May;287:112915. 
13 Zandifar A, Badrfam R. Iranian mental health during the COVID-19 epidemic. Asian J Psychiatr. 2020 Jun;51:101990.

14 Portugal. Ministério da Saúde. DGS. Casos de infecção por novo coronavírus (COVID-19): comunicado C160-75-v1 02/03/2020. Lisboa: Direcção Geral de Saúde; 2020.

15 Rubin GJ, Wessely S. The psychological effects of quarantining a city. BMJ. 2020; 368:m313.

16 Instituto Nacional de Estatística. Inquérito Nacional de Saúde 2014. Lisboa: INE; 2016.

17 WHO. Risk Communication and Community Engagement (RCCE) Action Plan Guidance: COVID-19 preparedness \& response. Geneva: WHO; 2020.

18 Wang C, Pan R, Wan X, Tan Y, Xu L, Ho CS. Immediate psychological responses and associated factors during the initial stage of the 2019 coronavirus disease (COVID-19) epidemic among the general population in China. Int J Environ Res Publ Health. 2020; 17(5):e1729.
19 Qiu J, Shen B, Zhao M, Wang Z, Xie B, Xu Y. A nationwide survey of psychological distress among Chinese people in the COVID-19 epidemic: implications and policy recommendations. Gen Psychiatr. 2020 Mar;33(2):e100213.

20 Li S, Wang Y, Xue J, Zhao N, Zhu T. The impact of COVID-19 epidemic declaration on psychological consequences: a study on active Weibo users. Int J Environ Res Public Health. 2020 Mar;17(6):e2032.

21 Wang Y, Di Y, Ye J, Wei W. Study on the public psychological states and its related factors during the outbreak of coronavirus disease 2019 (COVID-19) in some regions of China. Psychol Health Med. 2021 Jan;26(1):13-22.

22 Chakraborty K, Chatterjee M. Psychological impact of COVID-19 pandemic on general population in West Bengal: A cross-sectional study. Indian J Psychiatry. 2020 May-Jun; 62(3):266-72.
23 Sønderskov KM, Dinesen PT, Santini ZI, Østergaard SD. The depressive state of Denmark during the COVID-19 pandemic. Acta Neuropsychiatr. 2020 Aug;32(4):226-8.

24 González-Sanguino C, Ausín B, Castellanos MÁ, Saiz J, López-Gómez A, Ugidos C, et al. Mental health consequences during the initial stage of the 2020 Coronavirus pandemic (COVID-19) in Spain. Brain Behav Immun. 2020 Jul;87:172-6.

25 Brooks SK, Webster RK, Smith LE, Woodland L, Wessely S, Greenberg N, et al. The psychological impact of quarantine and how to reduce it: rapid review of the evidence. Lancet. 2020 Mar;395(10227):912-20.

26 Pappa S, Ntella V, Giannakas T, Giannakoulis VG, Papoutsi E, Katsaounou P. Prevalence of depression, anxiety, and insomnia among healthcare workers during the COVID-19 pandemic: A systematic review and metaanalysis. Brain Behav Immun. 2020 Aug;88: 901-7. 